\title{
A possible case of levamisole-induced pauci-immune focal necrotising and crescentic glomerulonephritis
}

R S Thalgahagoda ${ }^{1}$, R Ranawaka ${ }^{2}$, S Abeyagunawardena ${ }^{3}$, U I Karunadasa ${ }^{1}$, *Asiri Abeyagunawardena ${ }^{1}$

Sri Lanka Journal of Child Health, 2019: 48(1): 84-87

DOI: http://dx.doi.org/10.4038/sljch.v48i1.8661

(Keywords: Levamisole, drug-induced vasculitis, pauci-immune necrotising glomerulonephritis, crescentic, nephrotic syndrome)

\section{Background}

Levamisole (LEV) has been used successfully in the management of nephrotic syndrome, various autoimmune disorders, and colon and breast cancers in humans ${ }^{1-3}$. It has been shown to reduce the relapse rate in frequently relapsing and steroid dependent nephrotic syndrome as a monotherapy ${ }^{4}$ or with the combination of alternate day prednisolone ${ }^{5-7}$. Levamisole has the ability to act as a hapten. As suggested by recent literature, this might result in an altered immune response due to the increased formation of antibodies to various antigens ${ }^{8}$. Due to a number of cases reporting its adverse effects ${ }^{9,10}$, especially LEV-induced vasculopathy ${ }^{11,12}$, LEV was withdrawn from use in humans in the United States and Canada ${ }^{13}$.

Drug-induced vasculitis is the most common form of vasculitis ${ }^{14}$. It may be difficult to differentiate between drug-induced and idiopathic vasculitic conditions. A way of distinguishing between these two conditions is withdrawal of the offending drug. Affected individuals usually present with cutaneous manifestations, arthralgia, leucopenia and positive anti-neutrophil cytoplasmic antibodies (ANCA) in high titres. A predilection for ear lobe involvement is seen. End-organ involvement however is a rare presentation of LEV induced vasculitis. Here we report a 12 year old girl who developed pauciimmune focal necrotising and crescentic glomerulonephritis following long term use of LEV.

${ }^{1}$ Faculty of Medicine, University of Peradeniya, Sri Lanka, ${ }^{2}$ Faculty of Medicine, University of Colombo, Sri Lanka, ${ }^{3}$ Teaching Hospital, Peradeniya, Sri Lanka

*Correspondence: asiriabey26@gmail.com (Received on 26 May 2017: Accepted after revision on 28 July 2017)

The authors declare that there are no conflicts of interest

Personal funding was used for the project.

Open Access Article published under the Creative

Commons Attribution CC-BY (cc)

\section{Case report}

A 12 year old girl, a diagnosed patient with frequently relapsing steroid-sensitive nephrotic syndrome presented with a purpuric rash and nodules over upper and lower limbs. There was no arthralgia or arthritis. There were no urinary symptoms and she had a normal urine output. She had been on LEV $(2.5 \mathrm{mg} / \mathrm{kg})$ on alternate days for two and half years and had a relapse free period of one year. Previous laboratory tests performed 3 months earlier revealed a creatinine level of $56 \mu \mathrm{mol} / 1$ and an inactive urinary sediment.

On examination, she was pale but there was no oedema, lymphadenopathy or hepatosplenomegaly. Both upper and lower limbs revealed palpable purpura and a few skin nodules. Ear lobe involvement with purpura was also seen. The rest of the systemic examination was clinically unremarkable except for a marginally elevated blood pressure of 134/72 mmHg. Her urine dipstick showed 2+ protein and microscopic haematuria. Urine albumin/creatinine ratio was $156 \mathrm{mmol} / \mathrm{mg}$. Laboratory testing showed a white blood cell (WBC) count of 3600 per cu mm (normal range of 4000-11000 per cu $\mathrm{mm}$ ), a haemoglobin level of $7.8 \mathrm{~g} / \mathrm{dl}$ and a platelet count of 127,000 per $\mathrm{cu} \mathrm{mm}$ (normal range of 150,000-400,000 per cu mm). Erythrocyte sedimentation rate was $110 \mathrm{~mm}$ in first hour and renal function revealed serum creatinine of $88 \mu \mathrm{mol} / 1$.

Anti-neutrophil cytoplasm antibodies (ANCA) were positive in high titres. Anti-nuclear antibodies and double standard DNA antibodies were negative. Normal complement C3 and C4 levels were observed. An ultrasound scan showed slightly enlarged kidneys and no other remarkable findings. She underwent both renal and bone marrow biopsies. Bone marrow biopsy findings were not in favour of malignancy or aplasia. Pathological findings of the renal biopsy were consistent with pauci-immune focal necrotising and crescentic glomerulonephritis (Figure 1 and 2). 


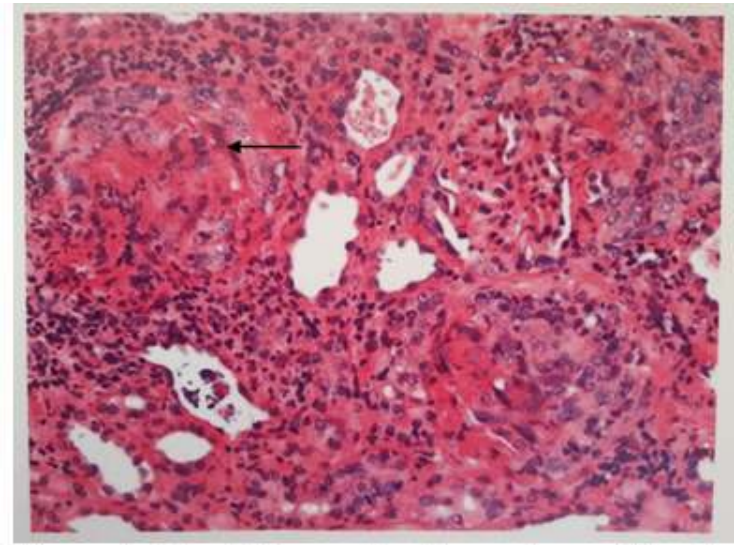

Figure 1: Renal biopsy showing regions of focal necrotizing glomerulonephritis

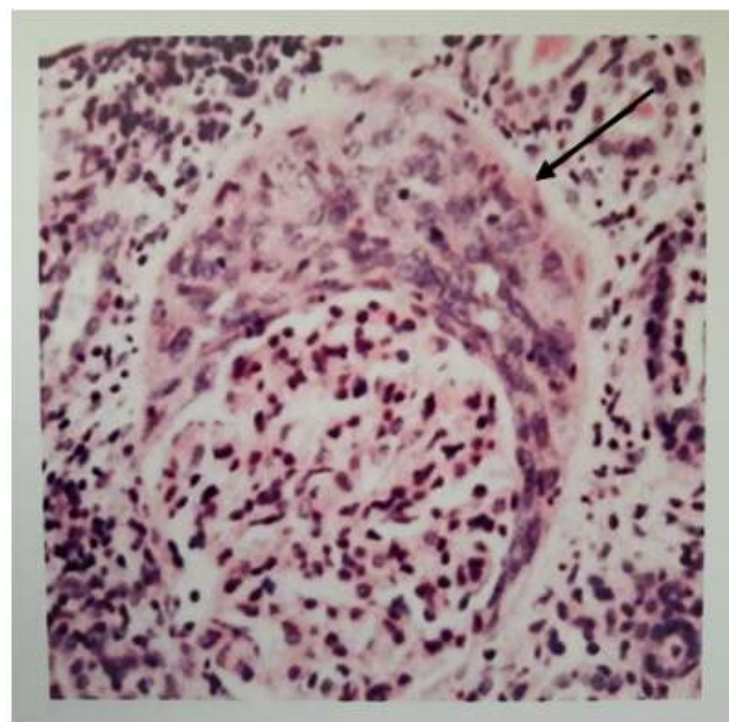

Figure 2 Renal biopsy showing crescent formation

LEV was stopped on admission. The patient received 3 doses of methyl prednisolone at $600 \mathrm{mg} / \mathrm{m}^{2}$ on consecutive days followed by the first dose of intravenous cyclophosphamide. She was then commenced on oral prednisolone at $60 \mathrm{mg} / \mathrm{m}^{2}$ daily for 4 weeks and a further two doses of intravenous cyclophosphamide were given at monthly intervals.

One month after the commencement of treatment, the urine albumin/creatinine ratio improved to 44 $\mathrm{mg} / \mathrm{mmol}$ and prednisolone was reduced to a 40 $\mathrm{mg} / \mathrm{m}^{2}$ alternate day regime. All three cell lines showed improvement after two weeks of stopping LEV. At the three month follow-up, urine albumin/creatinine ratio was normal, renal functions revealed serum creatinine of $62 \mu \mathrm{mol} / 1$ and titres of ANCA came down significantly. Tapering off of prednisolone is ongoing to maintain remission in NS.
Discussion
Levamisole is an anthelmintic drug with immunomodulatory properties. It has been successfully used in a dose of $2.5 \mathrm{mg} / \mathrm{kg}$ every other day, alone or in conjunction with every other day prednisolone for frequently relapsing nephrotic syndrome and steroid dependent nephrotic syndrome. Its steroid-sparing effect combined with minimal side effects is the main advantage of LEV. There is accumulating evidence to suggest that LEV remains an attractive alternative which could contribute towards a reduction of the maintenance dose of corticosteroids and prolongation of the period of remission ${ }^{5-7,15-17}$. However, LEV has not received approval for this indication in Europe. While difficulty in acquiring this drug may be one reason, the lack of sufficient evidence for its effectiveness could be another. In contrast, in the Asian subcontinent LEV is being used widely.

There are several case reports of LEV induced vasculopathy following use of LEV-adulterated cocaine in Europe and USA. Patients commonly presented with purpuric skin rash or bullae with ear involvement, arthralgia, leucopenia and positive ANCA in high titres. However, renal and pulmonary involvement are rarely seen in LEVinduced vasculitis. In a study by McGrath et $a l^{18}$ on 30 patients with ANCA positivity associated with LEV contaminated cocaine use, 8 patients showed abnormal urinalysis at diagnosis. Of the two patients who developed severe acute kidney injury, one had a renal biopsy which revealed pauciimmune focal necrotising and crescentic glomerulonephritis. Both these patients ultimately had chronic kidney disease, although their renal functions improved with immunosuppressive treatment.

Cutaneous vasculitis is known to occur in patients having prolonged treatment with LEV, as opposed to the minority who develop a systemic druginduced syndrome ${ }^{19}$. It usually affects the skin and sometimes the subcutaneous part of the $\operatorname{skin}^{20}$, but sometimes also the kidney and the lungs ${ }^{21}$. If LEV is withdrawn early, there is usually complete recovery whilst if $\mathrm{LEV}$ is withdrawn late, immunosuppressive therapy may be needed ${ }^{14}$. Patients with drug induced vasculitis typically harbour ANCA directed to one or more neutrophil cytoplasm antigens and it seems that ANCA appeared in the blood sometimes before the clinical manifestations.

In our case, the child had been on LEV $(2.5 \mathrm{mg} / \mathrm{kg})$ on alternate days for two and a half years. Even though she had been monitored with regular full blood counts, ANCA in serum was not performed. We have seen a remarkable improvement of her skin manifestations and cell line indices soon after 
withdrawing LEV. After 3 months of immunosuppressive therapy, urine albumin/ creatinine ratio had become normal and renal functions returned to the baseline. These findings indicate that immunosuppressive therapy could be given for a shorter time than in primary ANCAassociated vasculitis and long term maintenance therapy may not be needed.

One could argue that this was a case of idiopathic pauci-immune vasculitis which responded to the immunosuppression. We believe that the ear lobe involvement at the onset and the rapid response to discontinuation of levamisole are in favour of levamisole induced pauci-immune vasculitis with necrotising and crescentic glomerulonephritis. End organ involvement is a rare presentation of ANCA positive vasculitis induced by LEV.

\section{References}

1. Mutch R, Hutson P. Levamisole in the adjuvant treatment of colon cancer. Clinical Pharmacy 1991; 10(2):95-109.

PMid: 2009737

2. Vesely F, Pelikan A, Kodýdek J. Immunomodulation therapy of breast carcinoma with levamisole. Rozhledy $V$ Chirurgii. 1989; 68(4):233-9.

PMid: 2749387

3. Stevenson H, Green I, Hamilton J, Calabro B, Parkinson D. Levamisole: known effects on the immune system, clinical results, and future applications to the treatment of cancer. Journal of Clinical Oncology. 1991; 9(11):2052-66. https://doi.org/10.1200/JCO.1991.9.11.20 52

PMid: 1941064

4. Bagga A, Sharma A, Srivasta RN. Levamisole therapy in corticosteroiddependent nephrotic syndrome. Pediatric Nephrology 1997; 11:415-7. https://doi.org/10.1007/s004670050307 PMid: 9260236

5. Sumegi V, Haszon I, Ivanyi B, Bereczki C, Papp F, Turi S. Long-term effects of levamisole treatment in childhood nephrotic syndrome. Pediatric Nephrology 2004; 19:1354-60. https://doi.org/10.1007/s00467-004-16088

PMid: 15517419
6. Madani A, Isfahani ST, Rahimzadeh N, Fereshtehnejad SM, Hoseini R, Moghtaderi M, et al. Effect of levamisole in steroid-dependent nephrotic syndrome. Iranian Journal of Kidney Diseases 2010; 4: 292-6. PMid: 20852369

7. Al-Saran K, Mirza K, Al-Ghanam G, Abdelkarim M Experience with levamisole in frequently relapsing, steroiddependent nephrotic syndrome. Pediatric Nephrology 2006; 21:201-5. https://doi.org/10.1007/s00467-005-20809

PMid: 16222548

8. Arora N, Jain T, Bhanot R, Natesan S. Levamisole-induced

leukocytoclasticvasculitis and neutropenia in a patient with cocaine use: An extensive case with necrosis of skin, soft tissue, and cartilage. Addiction Science \& Clinical Practice 2012; 7(1):19.

https://doi.org/10.1186/1940-0640-7-19

PMid: 23186390 PMCid: PMC3509389

9. Parkinson DR, Cano PO, Jerry LM, Capek A, Shibata HR, Mansell PW, et al. Complications of cancer immunotherapy with levamisole. Lancet 1977; 1(8022): 1129-32. https://doi.org/10.1016/S01406736(77)923 86-8

10. Segal AW, Pugh SF, Levi AJ, Loewi G. Levamisole-induced arthritis in Crohn's disease. British Medical Journal 1977; 2(6086):555.

https://doi.org/10.1136/bmj.2.6086.555

PMid: 890414 PMCid: PMC1631477

11. Laux-End $\mathrm{R}$, Inabenit $\mathrm{D}$, Gerber HA, Bianchetti MG. Vasculitis associated with levamisole and circulating autoantibodies. Archives of Disease in Childhood 1996; 75(4):355-6. https://doi.org/10.1136/adc.75.4.355-b PMid: 8984931 PMCid: PMC1511759

12. Berman M, Paran D, Elkayam O. Cocaineinduced Vasculitis. Rambam Maimonides Medical Journal. 2016; 7(4):e0036. https://doi.org/10.5041/RMMJ.10263 PMid: 27824551 PMCid: PMC5101010 
13. Lee K, Ladizinski B, Federman D. Complications Associated With Use of Levamisole-Contaminated Cocaine: An Emerging Public Health Challenge. Mayo Clinic Proceedings 2012; 87(6):581-6. https://doi.org/10.1016/j.mayocp.2012.03. 010

PMid: 22677078 PMCid: PMC3498128

14. Radić M, Martinović K, Radić J. Druginduced vasculitis: a clinical and pathological review. The Netherlands Journal of Medicine. 2012; 70(1):12-17. PMid: 22271809

15. Boyer O, Moulder J, Grandin L, Somers M. Short and long-term efficacy of levamisole as adjunctive therapy in childhood nephrotic syndrome. Pediatric Nephrology 2008; 23: 575-80.

https://doi.org/10.1007/s00467-007-07087

PMid: 18204939

16. Ekambaram S, Mahalingam V, Nageswaran P, Udani A, Geminiganesan S, Priyadarshini S. Efficacy of levamisole in children with frequently relapsing and steroid-dependent nephrotic syndrome. Indian Pediatrics 2014; 51(5):371-3. https://doi.org/10.1007/s13312-014-04197

PMid: 24953577
17. Fu LS, Shien CY, Chi CS. Levamisole in steroid-sensitive nephrotic syndrome children with frequent relapses and/or steroid dependency: Comparison of daily and every-other day usage. Nephron Clinical Practice 2004; 97:c137-c41. https://doi.org/10.1159/000079172 PMid: 15331936

18. McGrath $\mathrm{M}$, Isakova $\mathrm{T}$, Rennke $\mathrm{H}$, Mottola A, Laliberte K, Niles J. Contaminated cocaine and antineutrophil cytoplasmic antibody-associated disease. Clinical Journal of the American Society of Nephrology 2011; 6(12):2799-805. https://doi.org/10.1159/000079172 PMid: 15331936

19. Vasoo S. Drug-induced lupus: an update. Lupus 2006; 15: 757-61. https://doi.org/10.1177/096120330607000 0

PMid: 17153847

20. Clinard V, Smith J. Drug-induced skin disorders. US Pharmacist 2012; 37(4):HS11-HS18.

21. Cooper J, Matthay R. Drug-induced pulmonary disease. Disease-a-Month 1987; 33(2):66-120. https://doi.org/10.1016/00115029(87)9002 1-6 